\title{
Characterization of Bovine and Human Neuronal Nicotinic Acetylcholine Receptors Using Monoclonal Antibodies
}

\author{
P. J. Whiting and J. M. Lindstrom \\ The Salk Institute for Biological Studies, San Diego, California 92138
}

\begin{abstract}
Neuronal acetylcholine receptors (AChRs), which bind nicotine with high affinity but do not bind $\alpha$-bungarotoxin $(\alpha \mathrm{Bgt})$, have recently been immunoaffinity-purified from chicken (Whiting and Lindstrom, 1986a) and rat (Whiting and Lindstrom, 1987a) brain using monoclonal antibodies (mAbs). Here we report the characterization of nicotinic AChRs of bovine and human brain using as probes mAbs prepared to AChRs from rat brain. Both the human and bovine brain AChRs exhibit high affinity for L-nicotine $\left(K_{\mathrm{i}}=16 \mathrm{nM}\right.$ for bovine $A C h R$ and $K_{\mathrm{i}}=6.5 \mathrm{nM}$ for human $\mathrm{AChR}$ ) and other cholinergic agonists, relatively lower affinity for cholinergic antagonists, and do not bind $\alpha$ Bgt. These AChRs are affinity-labeled with bromoacetylcholine and 4-( $\mathrm{N}$-maleimido)benzyltrimethylammonium iodide (MBTA) after reduction with dithiothreitol, indicating that amino acid residues homologous to cysteines 192 and 193 of $\alpha$ subunits of Torpedo electric organ AChRs are conserved. Immunoaffinity-purified bovine brain AChR consists of 2 types of subunit, $M_{r} 50,600$ and $M_{r} 74,400$. The $M_{r} 74,400$ subunit was affinity-labeled with ${ }^{3} \mathrm{H}-\mathrm{MBTA}$, indicating that it contains the ACh binding site. Thus, mAbs have proven to be excellent probes for these proteins, and have been used to show that neuronal nicotinic AChRs of chickens, rats, and cattle are macromolecules approximately 10 $S$ in size and composed of only 2 kinds of subunits: an AChbinding subunit and a structural subunit.
\end{abstract}

There is much behavioral, electrophysiological, and pharmacological evidence demonstrating the existence of nicotinic acetylcholine receptors (AChRs) in avian and mammalian brain (see Martin, 1986; Wonnacotl, 1987; and Lindstrom et al., 1987, for review). Until recently, the purification and molecular characterization of these neuronal AChRs has not been possible owing to the lack of suitable biochemical probes. The snake toxin $\alpha$-bungarotoxin $(\alpha \mathrm{Bgt})$ proved an invaluable tool for characterizing electric organ and muscle AChRs (see Popot and Changeux, 1984), but there is now much evidence to indicate

Received Sept. 23, 1987; revised Dec. 11, 1987; accepted Dec. 11, 1987.

We wish to thank RuShya Liu, John Cooper, and Diane Kramer for their technical help. We also wish to thank Dr. Mark McNamee of UC Davis for his generous gift of ${ }^{3} \mathrm{H}$-MBTA. This work was supported by grants to J. M. L. from the National Institutes of Health (NS1 1323), the Muscular Dystrophy Association, the Alexander S. Onassis Public Benefit Foundation, the Los Angeles and California Chapters of the Myasthenia Gravis Foundation, The Council for Tobacco Research-U.S.A., Inc., and the U.S. Army (DAMD17-86-C-6148). P. J. W. was supported by the Muscular Dystrophy Association Carl M. Pearson Postdoctoral Fellowship.

Correspondence should be addressed to Dr. Lindstrom, The Salk Institute, P.O. Box 85800 , San Diego, CA 92138.

Copyright (C) 1988 Society for Neuroscience $0270-6474 / 88 / 093395-10 \$ 02.00 / 0$ that it does not bind to avian and mammalian neuronal AChR, which gate cation channels (see Chiappinelli, 1985), and is therefore not a useful probe.

We have used monoclonal antibodies (mAbs) to purify and characterize neuronal nicotinic AChRs. A mAb prepared to AChRs from electric organ (mAb 35) cross-reacted with a nicotinic AChR in chicken brain (Lindstrom et al., 1983; Swanson et al., 1983). The immunoaffinity-purified AChR consisted of 2 types of subunit (Whiting and Lindstrom, 1986a). Affinitylabeling with ${ }^{3} \mathrm{H}-4-(N$-maleimido $)$ benzyltrimethylammonium iodide ( ${ }^{3} \mathrm{H}-\mathrm{MBTA}$ ) showed that the $M_{\mathrm{r}} 59,000$ subunit type bound ACh, while the $M_{\mathrm{r}} 49,000$ subunit type played a structural role (Whiting and Lindstrom, 1987b).This AChR bound ${ }^{3} \mathrm{H}$ nicotine and other cholinergic agonists with high affinity, bound cholinergic antagonists with relatively low affinity, and did not bind $\alpha \mathrm{Bgt}$ (Whiting and Lindstrom, 1986b). mAb 35 also identified the nicotinic AChR on chick ciliary ganglion neurons (Jacob et al., 1984; Smith et al., 1985, 1986; Halvorsen and Berg, $1986,1987)$. Antisera prepared to the AChR from chicken brain specifically blocked the function of AChRs on chick ciliary ganglia (Stollberg et al., 1986), suggesting that the AChRs of brain were also functional AChRs. mAbs prepared to AChR from chicken brain identified a second AChR subtype with similar or identical structural subunits, but ACh-binding subunits of $M_{\mathrm{r}} 75,000$ (Whiting et al., 1987c).

Chicken brain-derived $\mathrm{mAb} 270$, prepared to AChRs, crossreacts with $A C h R s$ from rat brain. This $\mathrm{mAb}$ has proven to be an extremely useful tool, and has been used to histologically locate (Swanson et al., 1987), purify, and characterize nicotinic AChRs from rat brain (Whiting and Lindstrom, 1986b, 1987a) and to identify a functional AChR on rat PC12 cells (Whiting et al., 1987d). Immunoaffinity-purified AChRs from rat brain also consist of 2 types of subunits, a structural subunit $M_{\mathrm{r}} 51,000$ and an ACh-binding subunit of $M_{\mathrm{r}} 79,000$. Like AChRs from chicken brain, the rat brain AChR has high affinity for nicotine and other cholinergic agonists, relatively lower affinity for antagonists, and does not bind $\alpha \mathrm{Bgt}$ (Whiting and Lindstrom, 1986b).

In an alternative approach to studying these neuronal nicotinic AChRs at the molecular level, several groups have used complementary DNA (cDNA) probes coding for subunits of muscle AChRs to isolate cDNA clones that code for putative neuronal AChR subunits by low-stringency cross-hybridization (Boulter et al., 1986; Goldman et al., 1987; Deneris et al., 1988; Nef et al., 1988; Schoepfer et al., 1988; Wada et al., 1988). Amino acid-sequence analysis of the subunits of immunoaffinity-purified AChRs has identified the AChR subunits for which many of these cDNAs code: the rat cDNA $\alpha 4$ (Goldman et al., 1987 ) codes for the $79,000 M_{\mathrm{r}} \mathrm{ACh}$-binding subunit of rat brain 
AChR (Whiting et al., 1987b); the chicken cDNA $\alpha 4$ (Nef et al., 1988; P. J. Whiting, R. Schoepfer, and J. M. Lindstrom, unpublished observations) codes for the 75,000 $M_{\mathrm{r}} \mathrm{ACh}$-binding subunit of chicken brain AChRs; the rat cDNA $\beta 2$ codes for the $51,000 M_{\mathrm{r}}$ structural subunit of AChRs from rat brain (Schoepfer et al., 1988); and the chicken cDNA n $\alpha$ (Nef et al., 1988) codes for the $49,000 M_{\mathrm{r}}$ structural subunit of AChRs from chicken brain (Schoepfer et al., 1988). Thus the mAb approach and the cDNA approach are beginning to converge.

The mAbs prepared to AChRs from chicken brain exhibited little or no cross-reactivity with AChRs from bovine and human brain (Whiting et al., 1987c). To overcome this problem, we have prepared a small library of $\mathrm{mAbs}$ to $\mathrm{AChRs}$ from rat brain, several of which exhibit excellent binding to AChRs from bovine and human brain. These mAbs have allowed the purification and characterization of these AChRs, as described below.

\section{Materials and Methods}

$A C h R$ purification. AChRs from rat brain were purified by immunoaffinity chromatography using $\mathrm{mAb} 270$ coupled to Sepharose-CL4B (8

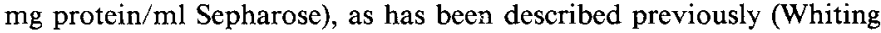
and Lindstrom, 1987a).

AChRs from bovine brain were purified by immunoaffinity chromatography using mAb 295 (see below) coupled to AFC resin (New Brunswick Scientific). Briefly, a bovine brain (obtained from a local abbatoir and stored at $-70^{\circ} \mathrm{C}$ ) was pulverized into small pieces while still frozen, and then 150-200 gm amounts were homogenized and the membranes isolated exactly as described previously (Whiting and Lindstrom, 1986a). The membranes were then extracted for $2 \mathrm{hr}$ at $4^{\circ} \mathrm{C}$ in $1 \mathrm{vol}$ of $2 \%$ Triton X-100 in $50 \mathrm{~mm}$ Tris, $\mathrm{pH} 7.2,1 \mathrm{~mm}$ EGTA, $1 \mathrm{~mm}$ EDTA, $5 \mathrm{~mm}$ iodacetamide, $5 \mathrm{~mm}$ benzamidine, and $2 \mathrm{~mm}$ phenylmethanesulfonyl fluoride (PMSF). The extract was centrifuged at 140,000 $\times g$ for $1 \mathrm{hr}$ in a Beckman Ti50.2 rotor, the clear supernatant collected, and the extract then gently shaken for $15 \mathrm{hr}$ at $4^{\circ} \mathrm{C}$ with $3 \mathrm{ml}$ of $\mathrm{mAb}$ $295-\mathrm{AFC} \mathrm{rcsin}(6.7 \mathrm{mg}$ protein $/ \mathrm{ml}$ resin). The resin was then loaded into a $10 \mathrm{ml}$ column and washed successively with approximately 200 $\mathrm{ml}$ of $10 \mathrm{~mm} \mathrm{Na}$ phosphate, $\mathrm{pH} 7.5,100 \mathrm{~mm} \mathrm{NaCl}$ (PBS) containing $0.5 \%$ Triton $\mathrm{X}-100,100 \mathrm{ml}$ of $10 \mathrm{~mm} \mathrm{Na}$ phosphate, $\mathrm{pH} 7.5,1 \mathrm{M} \mathrm{NaCl}$, $1 \mathrm{~mm}$ EDTA, $1 \mathrm{~mm}$ EGTA, $0.5 \%$ Triton X-100, and finally with $20 \mathrm{ml}$ of $20 \mathrm{~mm}$ Tris, $\mathrm{pH} 7.5,100 \mathrm{~mm} \mathrm{NaCl}$, with $0.1 \%$ Thesit detergent (Calbiochem). Bound AChR was eluted with 2-column volumes of AFC elution medium (New Brunswick Scientific) and dialyzed against 4 liters of $20 \mathrm{~mm}$ Tris, $\mathrm{pH} 7.5,100 \mathrm{~mm} \mathrm{NaCl}$, with $0.05 \%$ Thesit.

Purified AChRs from rat and bovine brain were radioiodinated as previously described (Whiting and Lindstrom, 1986a) by the lactoperoxidase-glucose oxidase method (BioRad), and kept at $4^{\circ} \mathrm{C}$ in PBS, $0.5 \%$ Triton X-100, containing $1 \mathrm{~mm} \mathrm{Na}$ azide and $10 \mathrm{mg} / \mathrm{ml} \beta$-lactoglobulin.

Detergent extracts of chicken brain, human brain, and rat muscle were also prepared as previously described (Whiting and Lindstrom, 1986a).

Immunization and spleen cell fusion. Female Lewis rats (6-8 weeks old) were immunized with immunoaffinity-purified rat brain AChR, both intact and denatured, in SDS, emulsified in 100-200 $\mu$ l of complete Freund's adjuvant (CFA). The rat that gave rise to the mAbs described was immunized intraperitoneally in PBS on day 1 with 10 pmol AChR in CFA, on day 17 with 5 pmol AChR (SDS-denatured) in CFA, on day 31 with 45 pmol AChR (half of which was SDS-denatured) in CFA, and finally on day 45 with $20 \mathrm{pmol} A C h R$ (half SDS-denatured). Five d later, the rat was killed and its spleen cells fused with the mouse myeloma cell line S194 15.XX0.BU1, using 50\% polyethylene glycol 4000 (Merck), as described in detail elsewhere (Hochschwender et al., 1985). Culture supernatants were screened for binding to ${ }^{125}$ I-labeled rat brain $A C h R$ by indirect immunoprecipitation using goat anti-rat IgG (Lindstrom et al., 1981). Supernatants that were positive (greater than twice background binding) upon retesting, and that, upon subsequent rescreening, exhibited binding to ${ }^{3} \mathrm{H}$-nicotine-labeled AChRs in detergent extracts of chicken brain (see below), were selected for recloning. Hybridoma cells were cloned directly in agarose (Hochschwender et al., 1985) and then grown in bulk in Iscove's medium, containing $1 \%$ fetal calf serum. Supernatants from mass cultures were concentrated to about $300 \mathrm{ml}$ using a Millipore Minitan concentrator and the im- munoglobulin fraction isolated by precipitation with $18 \%$ sodium sulfate, and then dialyzed against PBS containing $10 \mathrm{~mm}$ sodium azide.

mAb 295 was purified by chromatography upon S-Sepharose (Pharmacia). Briefly, $7 \mathrm{ml}$ of concentrated $\mathrm{mAb} 295$ were dialyzed against $50 \mathrm{~mm}$ morpholine-ethanesulfonic acid, $\mathrm{pH} 6,5 \mathrm{~mm} \mathrm{NaCl}$, and then applied to a $0.5 \times 10 \mathrm{~cm}$ column of S-Sepharose. Bound $\mathrm{mAb}$ was eluted with the same buffer containing $1 \mathrm{M} \mathrm{NaCl} ; 127 \mathrm{mg}$ of $\mathrm{mAb}$ was recovered.

${ }^{3} \mathrm{H}$-Nicotine binding assay. Antibody binding to AChRs in crude detergent extracts of brain was determined as described previously (Whiting and Lindstrom, 1986b). Briefly, detergent extract (200-600 $\mu$ l) was shaken gently for $15 \mathrm{hr}$ at $4^{\circ} \mathrm{C}$ with $100 \mu \mathrm{l}$ of culture supernatant or an appropriate amount of $\mathrm{mAb}$ or serum, and 20-30 $\mu \mathrm{l}$ of a 1:1 slurry of goat anti-rat IgG Sepharose $(8-12.5 \mathrm{mg} \mathrm{IgG} / \mathrm{ml}$ gel). After washing twice with $1 \mathrm{ml}$ of PBS containing $0.5 \%$ Triton X-100, the aliquots were incubated for $15 \mathrm{~min}$ at room temperature in $50 \mu \mathrm{l}$ of $20 \mathrm{nM}{ }^{3} \mathrm{H}$-nicotine DL- $N$-methyl ${ }^{3} \mathrm{H}$-nicotine, sp act $68.6 \mathrm{Ci} / \mathrm{mmol}$, obtained from $\mathrm{NEN}$ in the same buffer, and then rapidly washed 4 times at $4^{\circ} \mathrm{C}$ with $1 \mathrm{ml}$ of ice-cold PBS, $0.5 \%$ Triton X-100 by resuspending in the buffer and centrifuging for $20 \mathrm{sec}$ at $10,000 \times g$ in a microfuge. Bound protein was then eluted by incubating the gel for $15 \mathrm{~min}$ with $100 \mu \mathrm{l}$ of $2.5 \%$ SDS, $5 \% \beta$-mercaptoethanol, and then sampling into $5 \mathrm{ml}$ of scintillant $[5 \%$ Biosolve (Beckman), 4\% Liquifluor (NEN) in toluene]. Radioactivity was determined by scintillation counting. Specific binding was determined by subtraction of binding in the absence of antibody.

Polyacrylamide gel electrophoresis and western blot analysis. SDSPAGE and western blotting of protein samples were performed as previously described (Whiting and Lindstrom, 1986a), except that when probing western blots with antibodies, all incubations were carried out in PBS, $0.5 \%$ Triton $\mathrm{X}-100$, containing $5 \%$ (wt/vol) milk powder (Carnation) rather than bovine serum albumin. Polyacrylamide gels were silver-stained for protein (Oakley et al., 1980). Polyacrylamide gels containing ${ }^{125} \mathrm{I}$-protein were autoradiographed for $4-48 \mathrm{hr}$ at $-70^{\circ} \mathrm{C}$ using preflashed Kodak X-Omat AR film and an intensifying screen.

Enzymic digestion of ${ }^{225}$ I-labeled bovine brain AChR subunits. ${ }^{125} \mathrm{I}-$ Subunits were produced by preparative electrophoresis of the radiolabeled AChR and subsequent elution of the subunits (Whiting et al., 1986a). ${ }^{125}$ I-Subunits were treated with endoglycosidase-H (Miles) or Staphylococcus V8 protease (Miles), as has been described previously (Whiting and Lindstrom, 1986a).

\section{Results}

\section{Library of $m A$ bs to AChRs from rat brain}

A library of $9 \mathrm{mAbs}$ to AChRs from rat brain was prepared, the properties of which are shown in Table 1.

All of the $\mathrm{mAbs}$ bound $88-100 \%$ of the ${ }^{3} \mathrm{H}$-nicotine binding sites in detergent extracts of rat brain (data not shown). Additionally, AChRs immunoaffinity-purified from rat brain using mAbs 290, 295, and 299 had the same 2-subunit structure as AChRs purified on $\mathrm{mAb} 270$ (data not shown). These data argue against the existence of large amounts of any subtype of AChRs with a high affinity for nicotine with major differences in subunit structure, such as the AChR subtypes we identified in chicken brain (Whiting et al., 1987c).

Most of the mAbs proved to be conformation-dependent; only mAbs 292, 293, and 299 bound to denatured AChR subunits (Table 1). However, it is possible to predict the subunit spccificity of some of these mAbs by determining the proportion of ${ }^{3} \mathrm{H}$-nicotine binding sites depleted from a detergent extract of adult chicken brain. Adult chicken brain contains approximately equal amounts of $2 \mathrm{AChR}$ subtypes that have very similar or identical structural subunits, but different $\mathrm{ACh}$-binding subunits $\left(M_{\mathrm{r}} 59,000\right.$ or 75,000$)$ (Whiting et al., 1987c). The structural and $M_{\mathrm{r}} 75,000 \mathrm{ACh}$-binding subunits of chicken brain AChRs are homologous to the structural and ACh-binding subunits of rat brain AChR (Whiting and Lindstrom, 1987a). The chicken brain AChR subtypes can be distinguished by $\mathrm{mAb} 35$, which binds to the subtype with $M_{\mathrm{r}} 59,000 \mathrm{ACh}$-binding subunits, and 
mAb 285, which binds to the subtype with $M_{\mathrm{r}} 75,000 \mathrm{ACh}-$ binding subunits, while mAb 270, which is directed to the common structural subunit, binds to both subtypes (Whiting et al., 1987b; and Fig. 1). Both mAbs 293 and 299 depleted approximately half the ${ }^{3} \mathrm{H}$-nicotine binding sites from detergent extracts of chicken brain (Fig. 1), as would be expected since western blot data (Table 1) demonstrated that they are directed to the ACh-binding subunit. mAbs 290, 291, 297, and 298 all depleted the majority of AChRs from chicken brain extracts (Fig. 1), suggesting that they are directed to determinants on the structural subunit, which is shared by both chicken brain $\mathrm{AChR}$ subtypes.

Several of the mAbs cross-react with AChRs from bovine and human brain (Table 1) and were used as biochemical probes to study these AChRs. Detergent extracts of bovine brain contained $0.19-0.35 \mathrm{nM}^{3} \mathrm{H}$-nicotine binding sites $(0.43-0.64 \mathrm{pmol} /$ gm brain; 5 preparations), and detergent extracts of human brain contained $0.05-0.11 \mathrm{~nm}{ }^{3} \mathrm{H}$-nicotine binding sites $(0.05-0.21$ $\mathrm{pmol} / \mathrm{gm}$ brain; 7 preparations). The values for human brain cannot be considered representative of the number of ${ }^{3} \mathrm{H}$-nicotine binding sites in normal human brain because (1) the brains were from patients with Alzheimer's or Parkinson's disease, which are known to have reduced numbers of ${ }^{3} \mathrm{H}$-nicotine binding sites (Shimohama et al., 1986; Perry et al., 1987), and (2) only portions of a whole brain were extracted in each preparation; these may be relatively richer or poorer in ${ }^{3} \mathrm{H}$-nicotine binding sites.

The pharmacology of AChRs from bovine and human brain was studied using the immunoimmobilization assay described previously (Whiting and Lindstrom, 1986b). Figure 2 shows the binding of ${ }^{3} \mathrm{H}$-DL-nicotine to bovine and human brain AChRs immobilized upon $\mathrm{mAb} 290$. Scatchard analysis of binding curves gave $K_{\mathrm{d}}$ values of $2.6 \pm 0.3 \times 10^{-8} \mathrm{M}$ (mean $\pm \mathrm{SD} ; 2$ determinations) for bovine brain AChR, and $9.7 \pm 1.2 \times 10^{-9} \mathrm{M}$ (mcan $\pm \mathrm{SD} ; 3$ detcrminations) for human brain AChR. Additionally, the $K_{\mathrm{d}}$ value for ${ }^{3} \mathrm{H}$-DL-nicotine binding to bovine brain AChRs immobilized upon mAb 295 (not shown) was essentially identical to the $K_{d}$ obtained using mAb 290, sug-

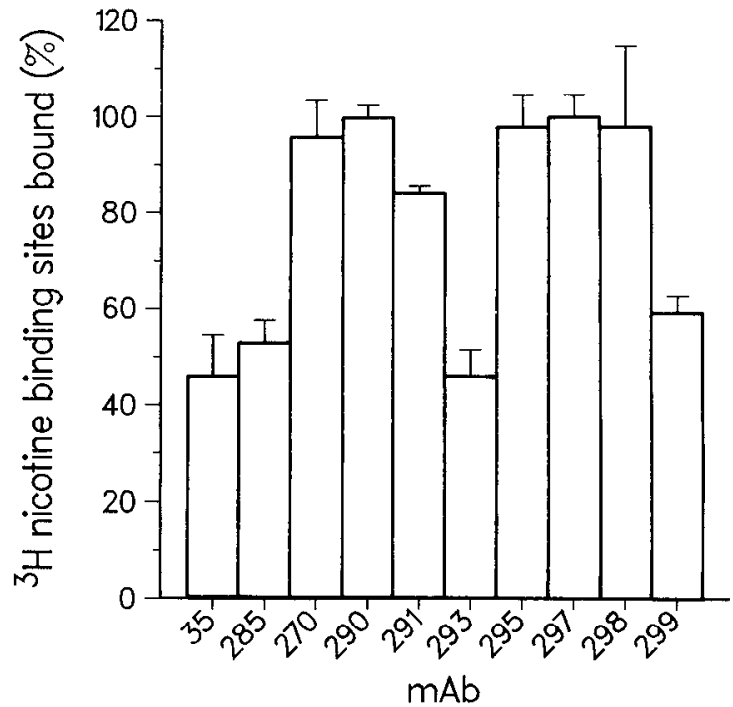

Figure 1. Depletion of AChRs from a detergent extract of chicken brain by mAbs to rat brain AChR. Triplicate aliquots $(350 \mu \mathrm{l})$ of chicken brain detergent extract were gently shaken for $15 \mathrm{hr}$ at $4^{\circ} \mathrm{C}$ with $50 \mu 1$ of goat anti-rat IgG Sepharose and $5 \mu 1$ of each mAb (titers shown in Table 1). The Sepharose was pelletted and the supernatants assayed for ${ }^{3} \mathrm{H}$-nicotine binding sites by a filter assay previously used by Schwartz et al. (1982) for studying ${ }^{3} \mathrm{H}$-ACh binding to rat brain membranes. Briefly, $100 \mu$ l triplicate aliquots of each supernatant were incubated for $1 \mathrm{hr}$ at $4^{\circ} \mathrm{C}$ with $20 \mathrm{nM}{ }^{3} \mathrm{H}$-nicotine and then diluted with $4 \mathrm{ml}$ of ice-cold $50 \mathrm{~mm}$ Tris, pH 7.4, and filtered through Whatman GF/B filters presoaked in $0.3 \%$ polyethyleneimine. The filters were washed 3 times with $4 \mathrm{ml}$ of the same buffer and bound radioactivity determined by scintillation counting. Nonspecific binding was determined by incubation in the presence of $1 \mathrm{~mm}$ nonradioactive nicotine and was subtracted. All values were expressed relative to the total ${ }^{3} \mathrm{H}$-nicotine binding sites (considered $100 \%$ ), determined by incubation with goat anti-rat IgG Sepharose alone.

gesting that the individual $\mathrm{mAbs}$ used here do not detectably affect the ligand-binding properties of the AChRs. Figure 3 shows the inhibition of ${ }^{3} \mathrm{H}$-nicotine binding to these AChRs by various cholinergic ligands. The $K_{\mathrm{i}}$ values for these ligands are shown

Table 1. Properties of mAbs to rat brain AChRs Binding to AChRs from brains of ${ }^{a}$

\begin{tabular}{|c|c|c|c|c|c|c|}
\hline \multirow[b]{2}{*}{$\mathrm{mAb^{b }}$} & \multirow[b]{2}{*}{ Chicken } & \multirow[b]{2}{*}{ Rat } & \multirow[b]{2}{*}{ Bovine } & \multirow[b]{2}{*}{ Human } & \multicolumn{2}{|c|}{ Subunit specificityc } \\
\hline & & & & & $\begin{array}{l}\text { Western blot } \\
\text { analysis }\end{array}$ & $\begin{array}{l}\text { Binding to } \\
\text { chicken }^{d} \text { brain } \\
\text { AChR subtype }\end{array}$ \\
\hline 290 & + & $+(26.9)$ & + & + & $?$ & structural \\
\hline 291 & + & $+(1.1)$ & - & - & $?$ & structural \\
\hline 292 & - & $+(9.4)$ & - & - & ACh binding & ACh binding \\
\hline 293 & + & $+(4.4)$ & - & + & ACh binding & ACh binding \\
\hline 294 & - & $+(1.5)$ & - & - & $?$ & not tested \\
\hline 295 & + & $+(0.5)$ & + & + & $?$ & structural \\
\hline 297 & + & $+(1.0)$ & + & + & $?$ & structural \\
\hline 298 & + & $+(0.7)$ & + & + & $?$ & structural \\
\hline 299 & + & $+(31.2)$ & - & + & ACh binding & ACh binding \\
\hline
\end{tabular}

a Binding of mAbs to native AChR in detergent extracts of brain was determined by a previously described assay (Whiting and Lindstrom, 1986b; see Materials and Methods). The anti-rat brain AChR titer (micromoles of ${ }^{3} \mathrm{H}$-nicotine binding sites bound per liter of $\mathrm{mAb}$ ) is shown in parentheses. None of the $\mathrm{mAbs}$ exhibited binding to either the $\alpha \mathrm{Bgt}-\mathrm{binding}$ protein from rat brain or the rat muscle $\mathrm{AChR}$, as measured by immunoprecipitation of ${ }^{125} \mathrm{I}-\alpha \mathrm{Bgt}$ binding sites (data not shown).

${ }^{b}$ All mAbs are IgG, as determined by SDS-PAGE analysis.

' Determined by probing western blots of immunoaffinity-purified rat brain AChR with mAbs. The question mark (?) indicates that these $\mathrm{mAbs}$ failed to bind to denatured subunits, and are thus conformation-dependent.

${ }^{a}$ See Figure 1. 


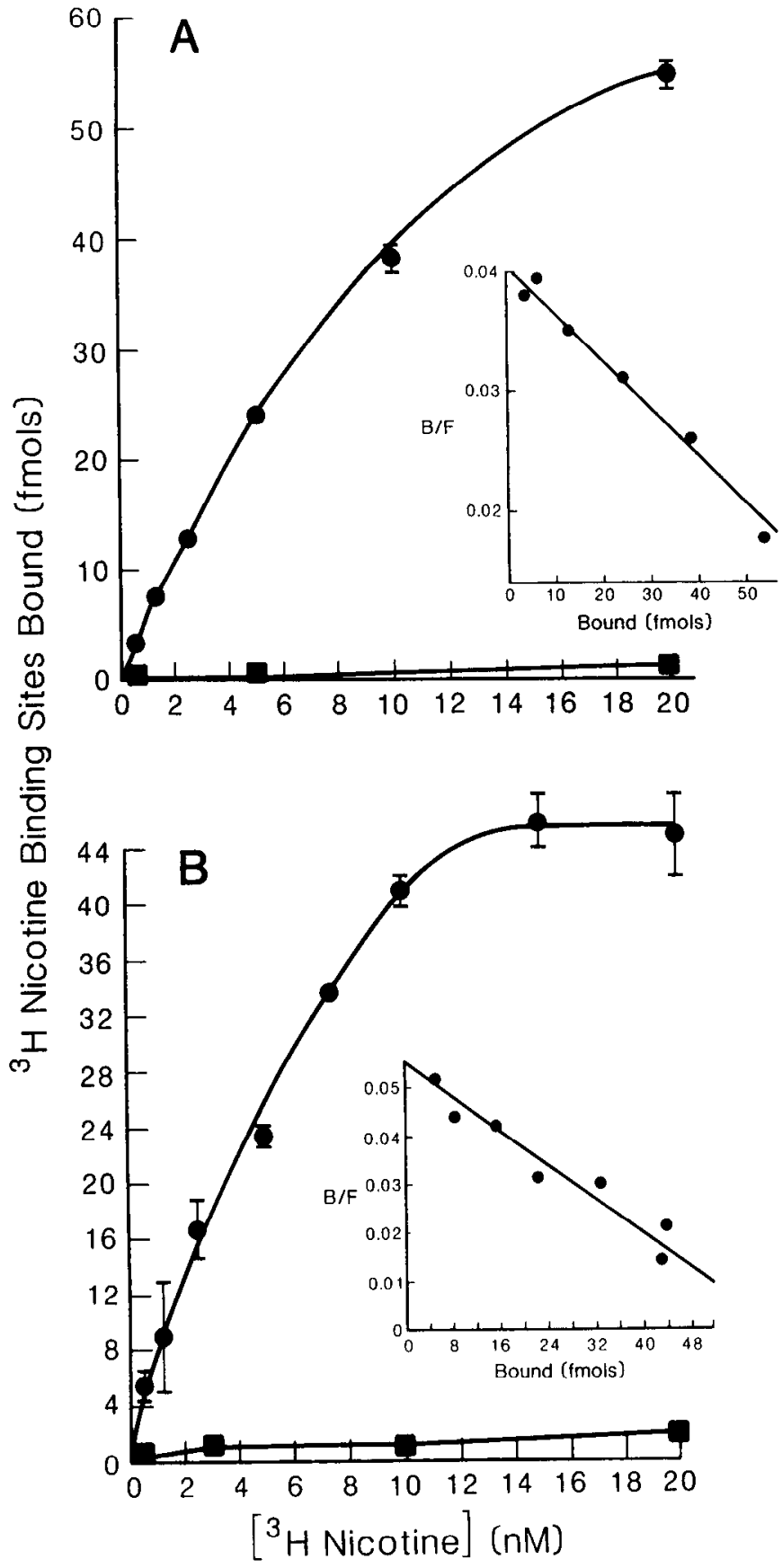

Figure 2. Binding of ${ }^{3} \mathrm{H}$-nicotine to AChRs from $(A)$ bovine brain and $(B)$ human brain. Aliquots of detergent extracts of $(A)$ bovine brain $(200$ $\mu \mathrm{l})$ or $(B)$ human brain $(600 \mu \mathrm{l})$ were gently shaken for $15 \mathrm{hr}$ at $4^{\circ} \mathrm{C}$ with $20 \mu \mathrm{l}$ of goat anti-rat IgG Sepharose and $0.5 \mu \mathrm{l}$ of $\mathrm{mAb} 290$. The aliquots were washed twice with $1 \mathrm{ml}$ of PBS, $0.5 \%$ Triton X-100, and incubated for $15 \mathrm{~min}$ at room temperature with $100 \mu$ l of the same buffer containing various concentrations of ${ }^{3} \mathrm{H}$-nicotine. Aliquots were rapidly washed 3 times at $4^{\circ} \mathrm{C}$ with $1 \mathrm{ml} \mathrm{PBS}, 0.5 \%$ Triton $\mathrm{X}-100$, and bound radioactivity was determined as described in Materials and Methods. Each point is the mean \pm SD of the values from 3 aliquots. Symbols indicate binding in the absence $(\theta)$ and presence $(\square)$ of nonradioactive $1 \mathrm{~mm}(\mathrm{D}, \mathrm{L})$ nicotine. The inserts show Scatchard analysis of the data.

in Table 2. AChRs from bovine and human brain exhibited high-affinity binding to L-nicotine and other cholinergic agonists, and relatively lower affinities to cholinergic antagonists. ${ }^{3} \mathrm{H}$-Nicotine binding was not inhibited by micromolar concentrations of $\alpha$ Bgt.

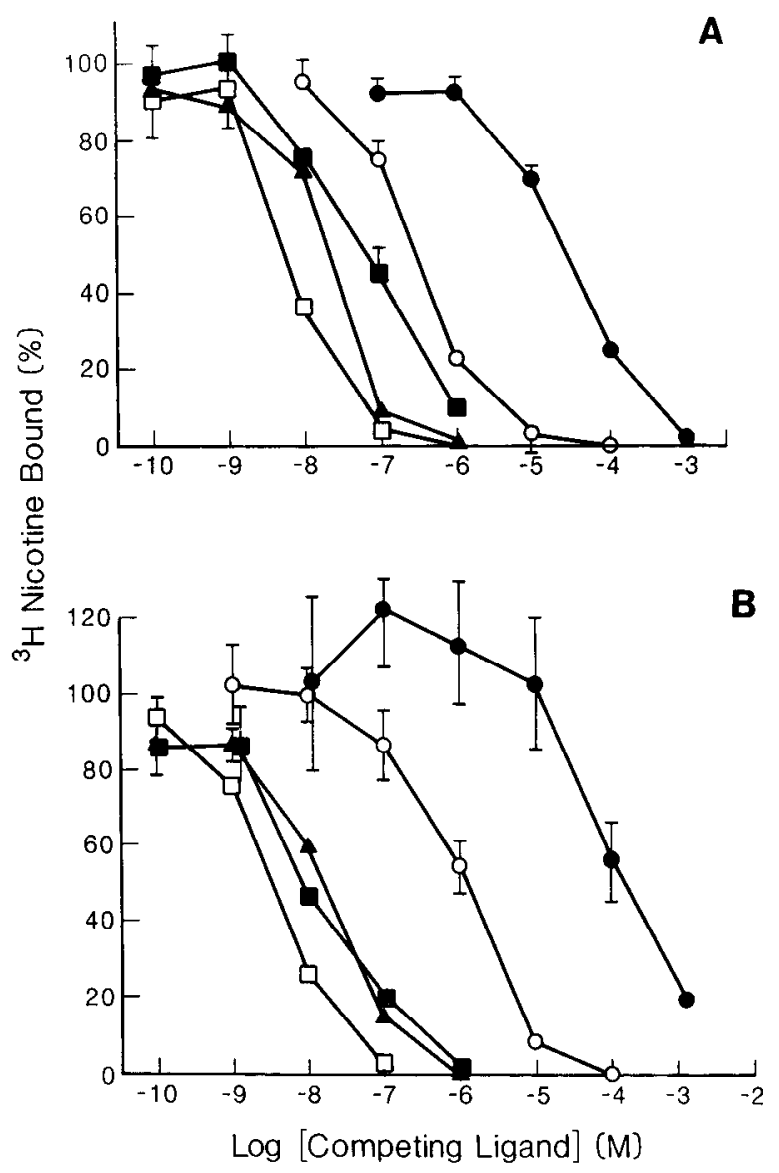

Figure 3. Inhibition of ${ }^{3} \mathrm{H}$-nicotine binding to immunoimmobilized $(A)$ bovine brain AChR and $(B)$ human brain AChR. Aliquots of detergent extracts of $(A)$ bovine brain $(250 \mu \mathrm{l})$ and $(B)$ human brain $(500$ $\mu$ l) were gently shaken for $15 \mathrm{hr}$ at $4^{\circ} \mathrm{C}$ with $20 \mu \mathrm{l}$ of goat anti-rat $\mathrm{IgG}$ Sepharose and $0.5 \mu \mathrm{l}$ of $\mathrm{mAb} 290$. The aliquots were washed twice with $1 \mathrm{ml}$ PBS, $0.5 \%$ Triton $\mathrm{X}-100$, and incubated for $15 \mathrm{~min}$ at room temperature with $100 \mu \mathrm{l}$ of the same buffer containing $10 \mathrm{nM}{ }^{3} \mathrm{H}-n i c o-$ tine, and various concentrations of competing ligands. Aliquots were rapidly washed 3 times with $1 \mathrm{ml}$ PBS containing $0.5 \%$ Triton X-100, and bound radioactivity was determined as described in Materials and Methods. Each point is the mean \pm SD of values from 3 aliquots. Nonspecific binding was determined by incubation in the absence of $\mathrm{mAb} 290$, and has been subtracted. All values are expressed relative to the ${ }^{3} \mathrm{H}$-nicotine bound in the absence of competing ligand (considered $100 \%)$. Symbols indicate cytisine ( $\square)$, L-nicotine $(\boldsymbol{\Delta})$, ACh ( $\square)$, carbachol $(\mathrm{O})$, and tubocurare (๑).

\section{Affinity-labeling of bovine and human brain AChRs with bromoacetylcholine and $M B T A$}

Bromoacetylcholine (BAC) and MBTA are nicotinic cholinergic affinity-labeling reagents that react with the AChR only after reduction of a disulfide bond between cysteine residues at positions 192 and 193 of the $\alpha$ subunit of Torpedo AChR, which are adjacent to the $\mathrm{ACh}$ binding site (Kao et al., 1984). We have previously shown that $\mathrm{AChRs}$ from chicken and rat brain can also be affinity-labeled with BAC and MBTA (Whiting and Lindstrom, 1987b). Figure 4 demonstrates that AChRs from bovine and human brain can be affinity-labeled by $\mathrm{BAC}$ and MBTA after reduction with dithiothreitol (DTT). BAC was approximately 1000 times more effective than MBTA at affinitylabeling brain AChRs. 
Table 2. Inhibition of $\mathrm{DL}^{-3} \mathrm{H}-$ nicotine binding to bovine and human brain AChR

\begin{tabular}{lrl} 
& \multicolumn{2}{l}{$K_{1}(\mathbf{M})$} \\
\cline { 2 - 3 } Ligand & $\begin{array}{l}\text { Bovine brain } \\
\text { AChR }\end{array}$ & \multicolumn{1}{l}{$\begin{array}{l}\text { Human brain } \\
\text { AChR }\end{array}$} \\
\hline Cytisine & $4.2 \times 10^{-9}$ & $1.1 \times 10^{-9}$ \\
L-Nicotine & $1.6 \times 10^{-8}$ & $6.5 \times 10^{-9}$ \\
ACh & $4.3 \times 10^{-8}$ & $2.7 \times 10^{-9}$ \\
Carbachol & $2.1 \times 10^{-7}$ & $4.1 \times 10^{-7}$ \\
Curare & $1.9 \times 10^{-5}$ & $4.7 \times 10^{-5}$ \\
$\alpha$ Bgt & $>10^{-6}$ & $>10^{-6}$ \\
Mecamylamine & n.d. & $>10^{-3}$ \\
Hexamethonium & n.d. & $>10^{-3}$
\end{tabular}

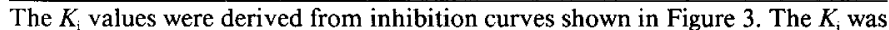
calculated from the experimentally determined $\mathrm{IC}_{50}$ value, using the equation, $K_{\mathrm{i}}$ $=\mathrm{IC}_{5 \mathrm{~d}} /\left(1+{ }^{3} \mathrm{H}\right.$-nicotine $\left./ K_{\mathrm{d}}\right)$. n.d., Not determined.

\section{Sucrose gradient analysis of $A C h R s$}

The macromolecular size of AChRs detergent-solubilized from bovine and human brain was analyzed by sucrose density-gradient centrifugation. Detergent-solubilized AChRs sedimented as single species slightly larger than Torpedo AChR monomers (Fig. 5), indicating that they are similar in size to AChRs from chicken brain (Whiting and Lindstrom, 1986a) and rat brain (Whiting and Lindstrom, 1987a). Evidence suggests that AChRs from brains of chickens and rats have the subunit composition $\alpha_{2-3} \beta_{2-3}$ (Whiting et al., $1987 \mathrm{~b}, \mathrm{c}$ ), and this is probably true of AChRs from cattle and humans.

\section{Structural characterization of AChR from bovine brain}

We have used the same approach to immunoaffinity-purify AChRs from bovine brain that was previously successful with AChRs from brains of chickens (Whiting and Lindstrom, 1986a; Whiting et al., 1987c) and rats (Whiting and Lindstrom, 1987a). Attempts to structurally characterize AChRs from human brain were not successful; when AChR from human brain was analyzed by probing western blots of the immunoaffinity-purified AChR with mAbs, or by affinity-labeling immunoimmobilized AChRs with ${ }^{3} \mathrm{H}-\mathrm{MBTA}$ and analyzing these by SDS-PAGE and fluorography, multiple bands were observed (data not shown). This suggested degradation of the AChR, probably during the postmortem period before the brain was removed and frozen.

AChR from bovine brain was immunoaffinity-purified on mAb 295 coupled to AFC resin (Table 3). This immunoaffinity column efficiently bound AChR from Triton X-100 extracts of bovine brain membranes. However, AChR eluted from the column using the AFC elution medium (supplied by New Brunswick Scientific) resulted in loss of ${ }^{3} \mathrm{H}$-nicotine binding activity, presumably because of denaturation of the AChR during the elution procedure. We have previously found that denaturation also occurs when $\Lambda \mathrm{ChR}$ is eluted from immunoaffinity columns using a low-pH buffer (Whiting and Lindstrom, 1986a, 1987a).

SDS-PAGE analysis and subsequent silver-staining demonstrated that AChRs from bovine brain consist of 2 types of subunit: $M_{\mathrm{r}} 50,600 \pm 700$ (mean $\pm \mathrm{SD} ; 4$ determinations) and $M_{\mathrm{r}} 74,400 \pm 1600$ (mean $\pm \mathrm{SD} ; 4$ determinations) (Fig. $6 A$ ). This same subunit pattern is also observed when the purified $A C h R$ is radioiodinated and analyzed by SDS-PAGE and subsequent autoradiography (Fig. 6B). When western blots of bovine brain AChR were probed with mAb 268 (directed to the
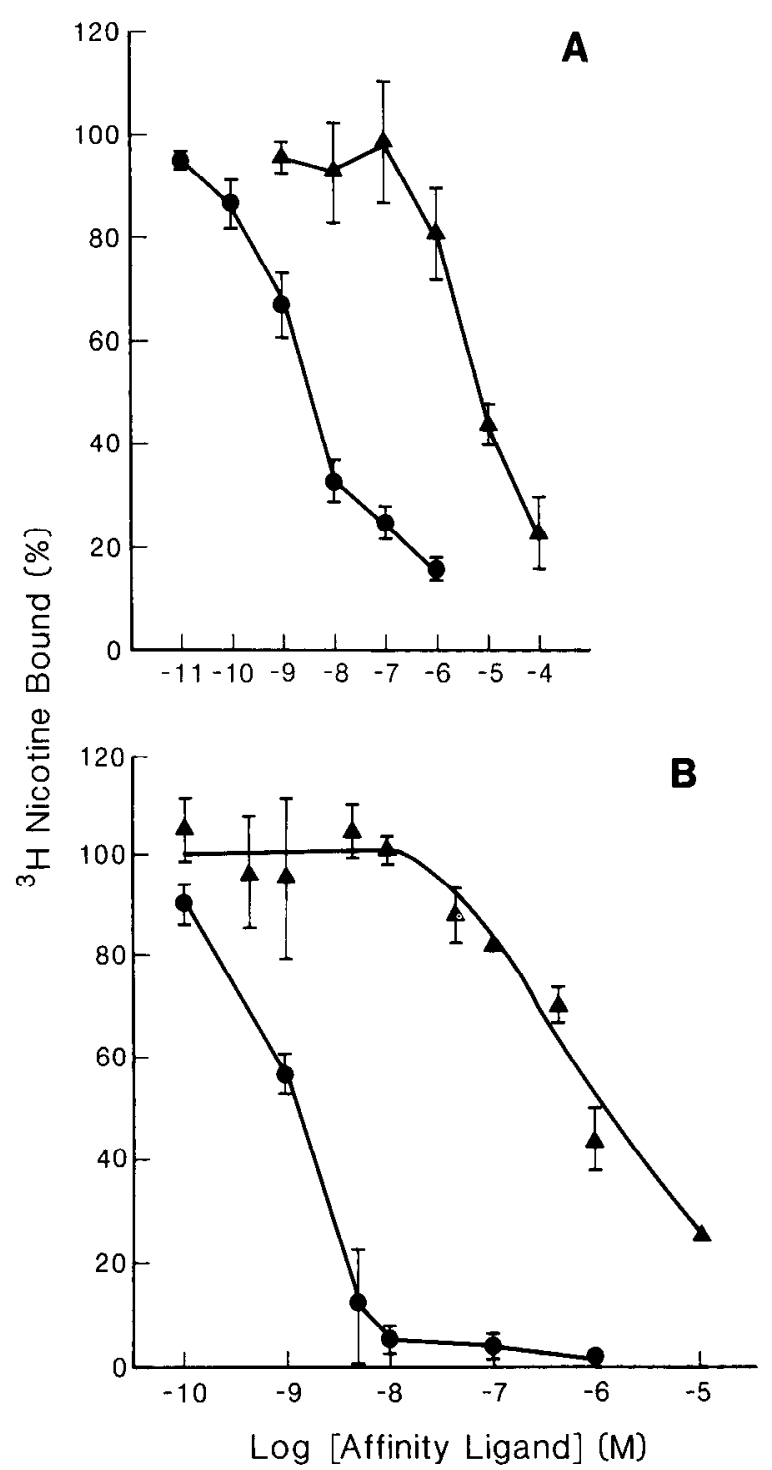

Figure 4. Affinity-labeling of $(A)$ bovine brain AChR and $(B)$ human brain AChR with BAC (๑) and MBTA $(\triangle)$. Aliquots of detergent extracts of $(A)$ bovine brain $(250 \mu \mathrm{l})$ or $(B)$ human brain $(400 \mu \mathrm{l})$ were gently shaken for $15 \mathrm{hr}$ at $4^{\circ} \mathrm{C}$ with $20 \mu \mathrm{l}$ of goat anti-rat IgG Sepharose and $0.5 \mu \mathrm{l}$ of mAb 290. The immunoimmobilized AChRs were then affinitylabeled as described elsewhere (Whiting and Lindstrom, 1987b). Briefly, aliquots were washed twice with $1 \mathrm{ml}$ PBS, $0.5 \%$ Triton X-100, then reduced for $40 \mathrm{~min}$ at room temperature with $200 \mu \mathrm{l}$ of the same buffer, containing $1 \mathrm{mM}$ DTT. Aliquots were washed with $1 \mathrm{ml} \mathrm{PBS,} 0.5 \%$ Triton X-100, and incubated for $5 \mathrm{~min}$ at room temperature in $100 \mu \mathrm{l}$ of the same buffer, containing various concentrations of BAC or MBTA. The aliquots were washed 3 times with $1 \mathrm{ml}$ of PBS, $0.5 \%$ Triton X-100, reoxidized by incubation for $10 \mathrm{~min}$ at room temperature with $200 \mu \mathrm{l}$ of $0.1 \mathrm{~mm}$ dithiobis (2-nitrobenzoic acid) in PBS, $0.5 \%$ Triton X-100, and then washed twice with a further $1 \mathrm{ml}$ PBS, $0.5 \%$ Iriton $\mathrm{X}-100$. The aliquots were then labeled with $20 \mathrm{nM}{ }^{3} \mathrm{H}$-nicotine and the ${ }^{3} \mathrm{H}$ nicotine binding sites determined as described in Materials and Methods. A parallel incubation was carried out, in which the affinity-labeling step was omitted; ${ }^{3} \mathrm{H}$-nicotine binding was considered as $100 \%$ and all other values were expressed relative to this. Nonspecific binding of ${ }^{3} \mathrm{H}$ nicotine was determined by incubation in the absence of $\mathrm{mAb} 290$, and was subtracted. Each point is the mean of triplicate aliquots.

structural subunit of AChRs from chicken and rat brain; Whiting et al., $1987 \mathrm{c}$ ), binding to the $50,000 M_{\mathrm{r}}$ subunit was observed (Fig. 6C), suggesting that it is the structural subunit of AChRs from bovine brain. 

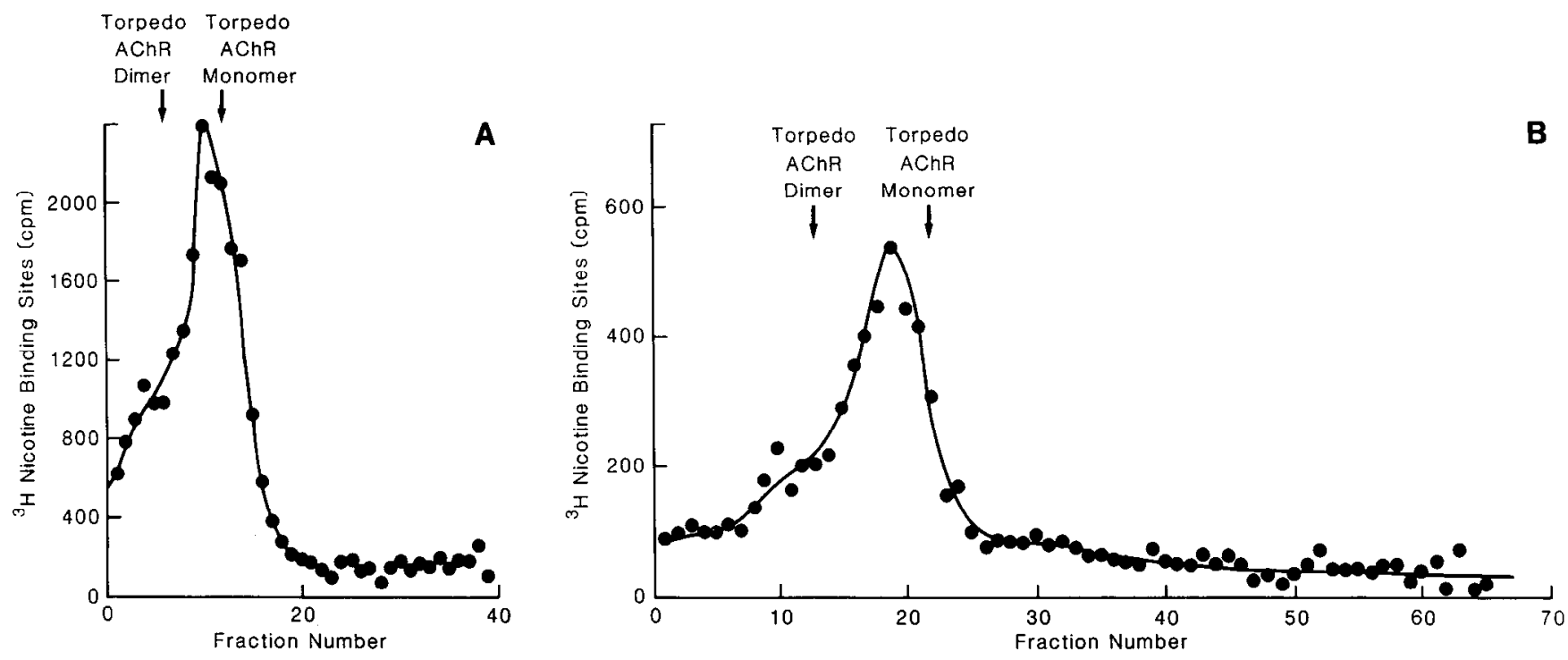

Figure 5. Sucrose gradient analysis of $(A)$ bovine and $(B)$ human brain AChR. Two milliliters of $(A)$ bovine or $(B)$ human brain detergent extract were loaded onto a $5-20 \%$ (wt/vol) sucrose gradient (in $10 \mathrm{~mm}$ Na phosphate, $\mathrm{pH} 7.5,0.1 \%$ Triton X-100) and centrifuged for $41 / 2$ hr in a VTI50 Beckman rotor at $4^{\circ} \mathrm{C}$ at $50,000 \mathrm{rpm} .40$-drop $(A)$ or 60 -drop $(B)$ fractions were collected and assayed directly for ${ }^{3} \mathrm{H}$-nicotine binding by incubation with $20 \mu \mathrm{l}$ goat anti-rat IgG Sepharose and $0.5 \mu \mathrm{lmAb} 290$, as described in Materials and Methods. As a standard, ${ }^{125} \mathrm{I}-\alpha \mathrm{Bgt}-\mathrm{labeled}$ Torpedo AChR was subjected to sucrose-gradient centrifugation in parallel and the fractions collected; radioactivity was determined by $\gamma$-counting.

To determine which subunit contained the ACh binding site, immunoimmobilized AChR from bovine brain was affinity-labeled with ${ }^{3} \mathrm{H}-\mathrm{MBTA}$ and analyzed by SDS-PAGE and fluorography (Fig. $6 D$ ). The $74,000 M_{\mathrm{r}}$ subunit was specifically labeled, suggesting that it contains the $\mathrm{ACh}$ binding site, and residues homologous to cysteines 192 and 193 of the $\alpha$ subunit of Torpedo AChR. The minor component at $M_{\mathrm{r}} 56,200$ may be a degradation product of the $74,000 M_{\text {r }}$ polypeptide. Alternatively, its size is similar to that of the ACh-binding subunit of chick ganglionic AChRs (Halvorsen and Berg, 1987) and to a putative ACh-binding subunit of a minor AChR subtype cDNA, $\alpha_{2}$, identified in rat brain (Wada et al., 1987). We also observed a similar minor affinity-labeled band in AChR purified from rat brain (Whiting and Lindstrom, 1987b). Thus, the affinity-labeled component at $M_{\mathrm{r}} 56,200$ could derive from traces of a copurified AChR subtype.

To further analyze the structure of AChR from bovine brain, the purified protein was radioiodinated and the 2 polypeptides isolated by preparative SDS-PAGE (Fig. 7A). When digested with endoglycosidase- $\mathrm{H}$, the structural subunit decreased in size by approximately 2000 (Fig. $7 B$ ), indicating that, like the $\alpha$ subunit of AChRs from Torpedo (Gershoni et al., 1983), muscle (Merlie et al., 1982), chicken brain (Whiting and Lindstrom, 1986b), and rat brain (Whiting and Lindstrom, 1987a), it has

Table 3. Purification of AChR from bovine brain (200 gm)

\begin{tabular}{llllr} 
& Volume & $\begin{array}{l}\text { Protein } \\
(\mathrm{mg})\end{array}$ & \multicolumn{3}{c}{\begin{tabular}{l}
${ }^{3} \mathrm{H}-\mathrm{N}$ binding sites \\
\cline { 5 - 6 } Purification step
\end{tabular}} & $\begin{array}{l}\text { (m) }) \\
\text { Extract }\end{array}$ & 435 & 3306 & 110 & 100 \\
\hline $\begin{array}{l}\text { Unbound to mAb 295 } \\
\text { AFC column }\end{array}$ & 435 & 3306 & 13.5 & 12 \\
Eluate & 22 & $<0.08$ & 2.25 & 2 \\
\hline
\end{tabular}

mannose-rich oligosaccharide side chains. By contrast, there was no obvious change in the size of the $\mathrm{ACh}$-binding subunit.

To investigate any obvious homologies between the structural and ACh-binding subunits, the isolated polypeptides were subjected to Staphylococcus V8 protease peptide mapping (Fig. 7C). The peptide maps of the 2 subunits were somewhat similar in their pattern, suggesting considerable homology.

\section{Discussion}

We have reported here the characterization of AChRs from bovine and human brain using $\mathrm{mAbs}$ prepared to $\mathrm{AChRs}$ from rat brain. This has been the third step in the process of using mAbs as probes for AChRs from fish to humans, to help follow the evolutionary tree: $\mathrm{mAb} 35$ prepared to $\mathrm{AChRs}$ from Electrophorus electric organ (Tzartos et al., 1981) was used as a probe for AChRs from chicken brain (Whiting and Lindstrom, 1986a); mAb 270, prepared to AChRs from chicken brain (Whiting et al., 1987c), was used as a probe for AChRs from rat brain (Whiting and Lindstrom, 1987a). Now, mAbs 290 and 295, prepared to AChRs from rat brain, have been used as probes for AChRs from bovine and human brains.

The AChRs from bovine and human brains are similar to the AChRs from chicken and rat brains. All exhibit high-affinity binding for L-nicotine and other cholinergic agonists, relatively lower affinity binding for antagonists, and do not bind $\alpha \mathrm{Bgt}$ (Table 2) (Whiting and Lindstrom, 1986b; Whiting et al., 1987c). However, the affinity of the AChR from bovine brain for L-nicotine $\left(K_{1}=16 \mathrm{nM}\right)$ was somewhat lower than the affinities of AChRs from chicken brain $\left(K_{\mathrm{i}}=1.1\right.$ and $1.6 \mathrm{nM}$ for the $2 \mathrm{AChR}$ subtypes; Whiting et al., $1987 \mathrm{c})$, rat brain $\left(K_{\mathrm{i}}=1.3 \mathrm{nM}\right.$; Whiting et al., $1987 \mathrm{~d})$, and human brain $\left(K_{\mathrm{i}}=6.5 \mathrm{nM}\right)$ for this ligand.

Like AChRs from chicken and rat brain (Whiting and Lindstrom, 1986b, 1987b), AChRs from bovine and human brain were affinity-labeled with BAC and MBTA, demonstrating that they have cysteine residues homologous to cysteines 192 and 193 of the $\alpha$ subunit of Torpedo AChR (Kao et al., 1984) close 
A

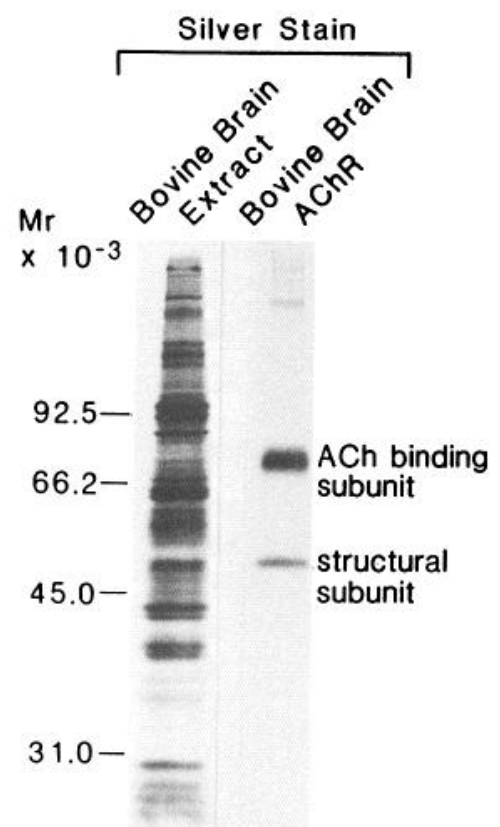

B

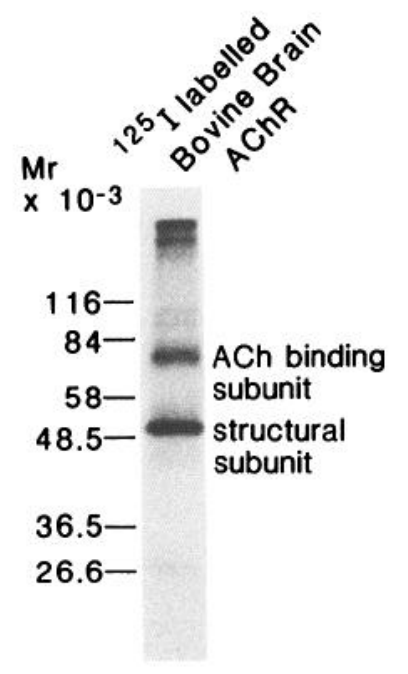

C

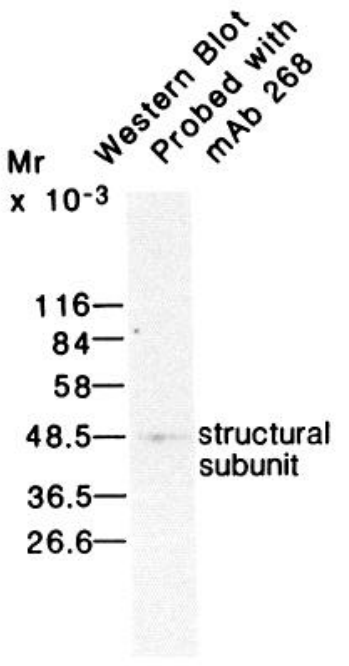

D

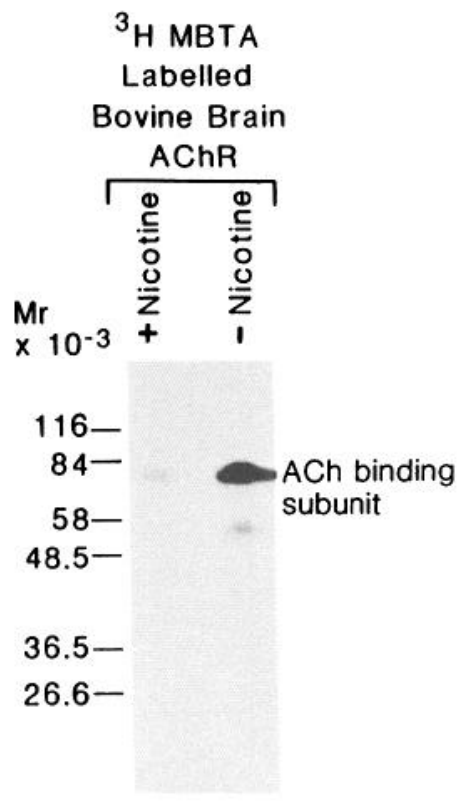

Figure 6. Structural characterization of bovine brain AChR. A, SDS-PAGE and silver-staining of bovine brain AChR immunoaffinity-purified upon mAb 295 AFC resin. B, SDS-PAGE and autoradiography of ${ }^{125}$ I-labeled bovine brain AChR. $C$, Western blot of immunoaffinity-purified bovine brain AChR probed with $\mathrm{mAb} 268$. D, SDS-PAGE and fluorography of bovine brain AChR (approximately 20 pmol of ${ }^{3} \mathrm{H}-$ nicotine binding sites per lane) affinity-labeled with ${ }^{3} \mathrm{H}-\mathrm{MBTA}$ in the presence or absence of $1 \mathrm{~mm}$ nicotine. Affinity-labeling was carried out as previously described in detail (Whiting and Lindstrom, 1987b). Molecular-weight markers ( $A$, BioRad markers; $B-D$, Sigma prestained markers) are indicated by the side of each lane.

to the ACh binding site. BAC (an agonist) was a much more effective affinity label than MBTA (an antagonist), which probably reflects the relatively higher (nм) affinity of these brain AChRs for agonists than for antagonists. This is in contrast to ganglionic-type nicotinic AChRs, such as those found in PC12 cells, where MBTA is a more effective affinity label than BAC, again probably reflecting the lower $(\mu \mathrm{M})$ affinity of those ganglionic-type AChRs for agonists (Leprince, 1983).

The subunit structure of the AChR from bovine brain (Fig. 6) is similar to that of the AChR subtype from chicken brain, with ACh-binding subunits of $M_{\mathrm{r}} 75,000$ (Whiting et al., 1987c), and to the AChR from rat brain (Whiting and Lindstrom, 1987a). The structural subunit of AChR from bovine brain is homologous to structural subunits of AChRs from chicken and rat brains, as demonstrated by the essentially identical $M_{\mathrm{r}}$ of the polypeptides, and the cross-reactivity of $\mathrm{mAb} 268$ on western blots (Fig. 6). Similarly, the 74,400 $M_{\mathrm{r}}$ ACh-binding subunit of AChRs from bovine brain is homologous to the $79,000 M_{\mathrm{r}} \mathrm{ACh}$ binding subunit of AChRs from rat brain (Whiting and Lindstrom, 1987a) and to the $75,000 M_{\mathrm{r}} \mathrm{ACh}$-binding subunit of one AChR subtype of chicken brain (Whiting et al., 1987c), as demonstrated by their very similar $M_{\mathrm{r}} \mathrm{s}$ and by the fact that they are all labeled by ${ }^{3} \mathrm{H}$-MBTA (Fig. 6) (Whiting and Lindstrom, 1987b). It is also possible to tentatively assign the same 2 -subunittype structure to the nicotinic AChR from human brain; when western blots of $\mathrm{AChR}$ from human brain were probed with mAb 268, binding was detected, although to multiple bands, suggesting degradation of a structural subunit (data not shown). Similarly, when AChR from human brain was affinity-labeled with ${ }^{3} \mathrm{H}-\mathrm{MBTA}$ and analyzed by SDS-PAGE and fluorography, specific labeling of several polypeptides was observed, the largest of which was $M_{\mathrm{r}} 79,000$, which would be the predicted size of the ACh-binding subunit (data not shown). It has not been possible to gather more convincing evidence on the structure of AChRs from human brain, owing to degradation of the protein, which probably occurred during the postmortem period before the brain was removed and frozen. The proteolytic nicking of these AChRs probably did not affect their pharmacological properties; Torpedo electric organ AChR, digested with proteases, remains fully functional in carbachol-induced ${ }^{22} \mathrm{Na}^{+}$flux (Lindstrom et al., 1980).

Birds and mammals may differ in their distribution of $\mathrm{AChR}$ subtypes. In adult chicken brain we found approximately equal amounts of 2 subtypes, differing in their ACh-binding subunits (Whiting et al., 1987c). In zebra finch brains there is immunohistological evidence for 2 similar subtypes (Watson et al., 1988). However, in both rat brain (Whiting and Lindstrom, 1987a) and bovine brains (Fig. 6), a predominant AChR subtype is observed corresponding to the chicken subtype with AChbinding subunits of $M_{\mathrm{r}} 75,000$. Another structure that is conserved in AChR from avian brain, but not in AChRs from mammalian brain, is the main immunogenic region (MIR). This is a domain on the extracellular surface of the $\alpha$ subunit of electric organ and muscle AChRs against which the majority of antibodies are directed in an immune response to AChRs (Tzartos and Lindstrom, 1980). mAbs directed to the MIR, such as mAb 35 (Tzartos et al., 1981), bind to the AChR subtype from chicken brain with an $M_{\mathrm{r}} 59,000 \mathrm{ACh}$-binding subunit (Swanson et al., 1983; Whiting and Lindstrom, 1986a; Whiting et al., $1987 \mathrm{c}$ ), but not to the subtype from chicken brain with an $M_{\mathrm{r}}$ 
A

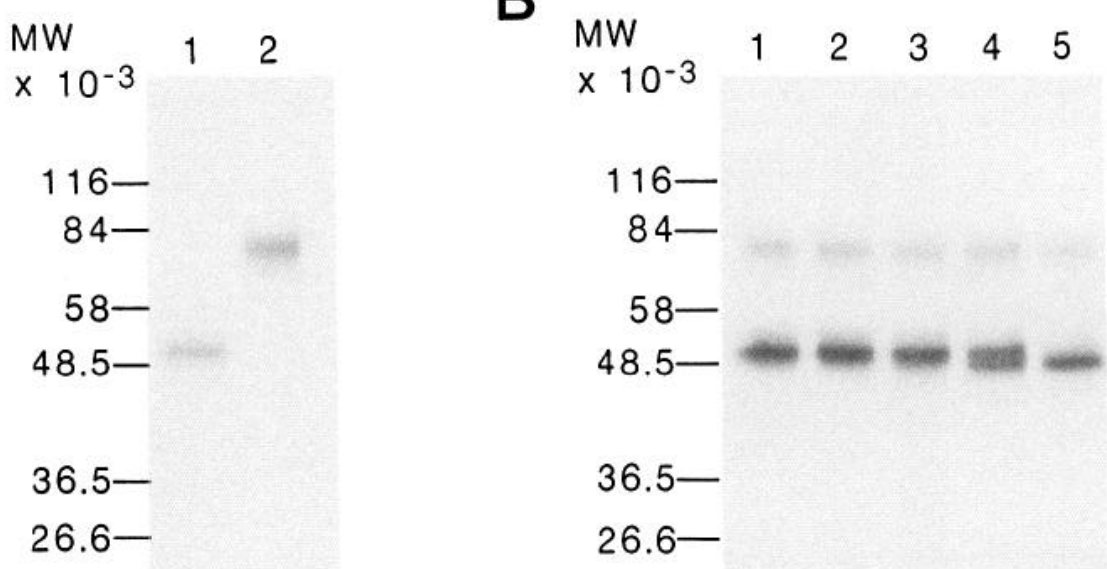

Figure 7. Enzymic digestion of bovine brain AChR. $A$, SDS-PAGE and autoradiography of purified structural subunits (lane 1 ) and ACh-binding subunits (lane 2) of ${ }^{125}$ I-labeled bovine brain AChR. B, Digestion of ${ }^{125}$ I-labeled bovine brain $\mathrm{AChR}$ with endoglycosidase-H. ${ }^{125}$ I-labeled subunits $(20,000$ $\mathrm{cpm}$ ) were incubated for $15 \mathrm{hr}$ at $37^{\circ} \mathrm{C}$ in $30 \mu \mathrm{l}$ of $50 \mathrm{~mm}$ citrate, $\mathrm{pH} 5.5$, containing $0.5 \%$ SDS and 50 mм DTT, and $0,0.002,0.02,0.2$, and 2 milliunits of endoglycosidase-H (lanes 1-5). Samples were then analyzed by SDS-PAGE and autoradiography. $C$, Digestion of ${ }^{125}$ I-labeled bovine brain AChR structural subunit (lanes $1-5$ ) and $\mathrm{ACh}$ binding subunit (lanes $6-10$ ) with Staphylococcus V8 protease. Subunits $(40,000 \mathrm{cpm})$ were incubated for $1 \mathrm{hr}$ at $37^{\circ} \mathrm{C}$ with various concentrations of protease (lanes 1 and $10,25 \mu \mathrm{g}$; lanes 2 and 9, $2.5 \mu \mathrm{g}$; lanes 3 and $8,0.25 \mu \mathrm{g}$; lanes 4 and $7,0.025 \mu \mathrm{g}$; lanes 5 and 6 , $0.0025 \mu \mathrm{g}$ ). PMSF was then added to a final concentration of $1 \mathrm{~mm}$, and the peptides resolved by SDS-15\% PAGE and autoradiography.

$\begin{array}{lllllllllll}\mathrm{MW} & 1 & 2 & 3 & 4 & 5 & 6 & 7 & 8 & 9 & 10\end{array}$

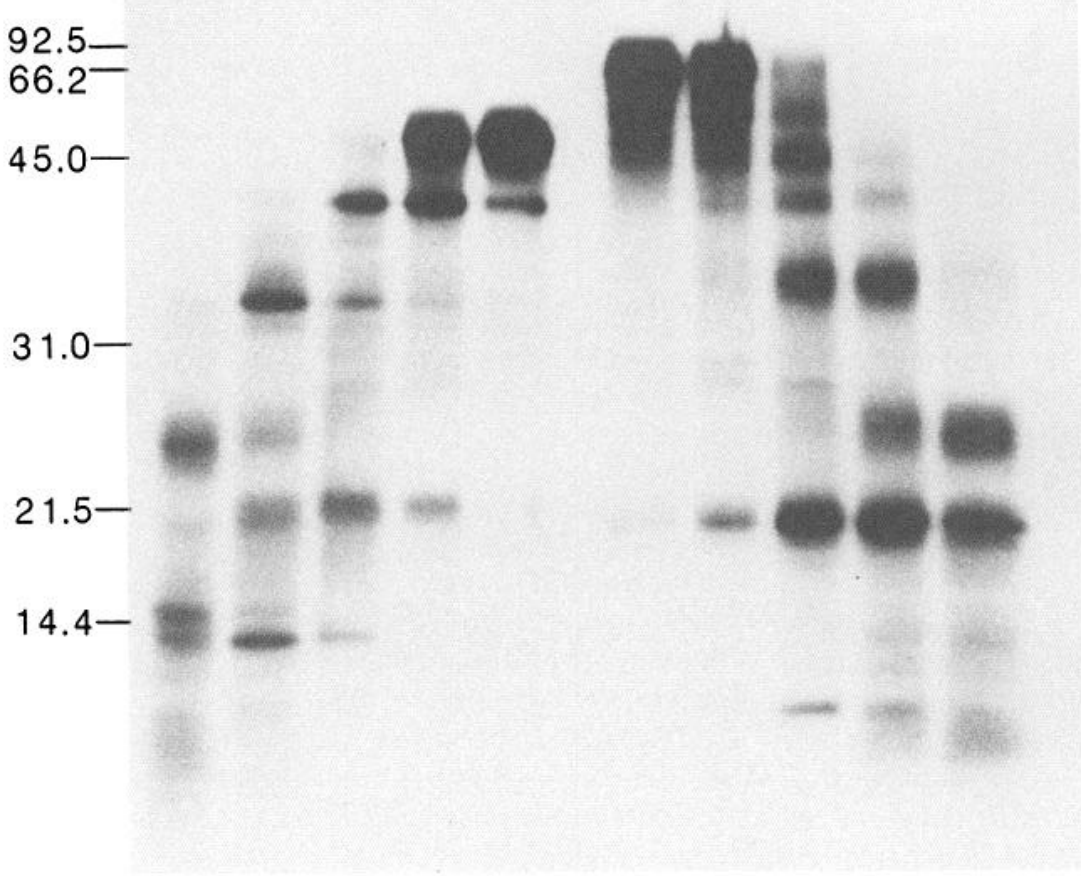

75,000 ACh-binding subunit, or to AChRs from rat brain (Whiting and Lindstrom, 1986b, 1987a), human brain (Whiting et al., 1987a), or bovine brain (data not shown).

It is interesting to note that mAb 35 has recently been demonstrated as binding to the ganglionic-type nicotinic $\mathrm{AChR}$ of bovine adrenal chromaffin cells (Higgins and Berg, 1987). Because mAb 35 does not bind to the AChR from bovine brain, it is clear that the AChRs from bovine brain and ganglia are antigenically somewhat different. In the future, comparison of the pharmacology and subunit structures of these $2 \mathrm{AChRs} \mathrm{should}$ prove informative.

The antigenic differences between ganglionic and brain $\mathrm{AChRs}$ suggest that at least one of their subunits is the product of different, but closely related, genes. This has been suggested previously by the observation that the AChRs of chick ciliary ganglia (Halvorsen and Berg, 1986) and PC12 cells (Kemp and Morley, 1986; Whiting et al., 1987d) have considerably lower affinities for nicotine and $\mathrm{ACh}$ compared to the nanomolar affinity of brain AChRs for these ligands (Whiting and Lindstrom, 1986b).

The concept of a nicotinic AChR gene family has been discussed previously (Conti-Tronconi et al., 1985; Boulter et al., 1986; Goldman et al., 1986, 1987; Whiting and Lindstrom, 1987c; Whiting et al., 1987b). Recent data indicate that a much 
larger "super" gene family exists (Grenningloh et al., 1987; Schofield et al., 1987; for review, see Linstrom et al., 1987). This gene family certainly includes the $\alpha, \beta, \gamma, \delta$, and $\epsilon$ subunits of the electric organ and muscle-type AChR. It also includes the putative neural AChR gene $\alpha 2$ (Wada et al., 1988), $\alpha 3$ (Boulter et al., 1986), $\alpha 4$ (Goldman et al., 1987; Nef et al., 1988), and $\beta 2$ or $n \alpha$ (Deneris et al., 1988; Nef et al., 1988). The cDNAs termed $\alpha 4$ have been shown to code for the $M_{\mathrm{r}} 75,000$ (chicken) and $M_{\mathrm{r}} 79,000$ (rat) ACh-binding subunits (Whiting et al., 1987b; P. J. Whiting, F. Esch, and J. M. Lindstrom, unpublished observations) of neuronal AChRs with high affinity for nicotine. The cDNAs $\beta 2$ (rat) and n $\alpha$ (chicken) have been shown to code for the structural subunit of AChRs from chicken and rat brain which have high affinity for nicotine (Schoepfer et al., 1988). The identities of the proteins coded for by $\alpha 2$ and $\alpha 3$ have yet to be established. It is possible that $\alpha 3$ is the ACh-binding subunit of the ganglionic-type AChR of PC12 cells and chick ciliary ganglion neurons (Boulter et al., 1986; Boyd et al., 1987). Ganglionic AChRs may, however, have the same structural subunit (coded for by cDNAs $\beta 2$ and $n \alpha$ ) as the brain-type AChRs, as is suggested by the fact that $\beta 2$ was isolated from PC12 cells (Deneris et al., 1988), and mAb 270, which is directed to the structural subunit, binds to AChRs of PC12 cells (Whiting et al., 1987d). The identity of the subunit coded for by cDNA $\alpha 2$ remains obscure. At the protein level, although we have clear evidence of AChR subtypes in chicken brain (Whiting et al., 1987c), we have as yet only limited evidence for multiple AChR subtypes in mammalian brains (e.g., the minor affinity-labeled band in Fig. 6, or see Whiting and Lindstrom, 1987b).

Recently, the cloning and sequencing of cDNA coding for the $\alpha$ subunit of the glycine receptor (Grenningloh et al., 1987) and for the $\alpha$ and $\beta$ subunits of the GABA receptor (Schofield et al., 1987 ) indicated that they show significant homology to members of the AChR family. Thus, the nicotinic AChR family can now be expanded and considered as a ligand-gated receptor "super" family.

In humans, the nicotinic AChR in brain has been implicated in several diseases. It is likely that the AChR is the site through which nicotine exerts its addictive effects in smokers (see Wonnacott, 1987). Additionally, it has been reported that the number of ${ }^{3} \mathrm{H}$-nicotine and ${ }^{3} \mathrm{H}$-ACh binding sites is reduced in the brains of patients with Alzheimer's (Flynn and Mash, 1986; Shimohama et al., 1986; Perry et al., 1987) and Parkinson's (Perry et al., 1987) diseases, although these reductions are probably simply the manifestation of cell death. In an attempt to demonstrate involvement of the neuronal nicotinic $A C h R$ in human disease, we looked for the presence of autoantibodies to human brain AChR in the sera of patients with several neurological diseases, including myasthenia gravis, a disease in which autoantibodies are produced to the muscle AChR (Lindstrom, 1985). In no case did we detect binding of any antibodies to the AChR from human brain (Whiting et al., 1987a), arguing against a neuronal ACh R antibody-mediated autoimmune etiology for Alzheimer's disease, Parkinson's disease, Guillain-Barré syndrome, multiple sclerosis, or Eaton Lambert myasthenic syndrome. Additionally, this demonstrated that in patients with myasthenia gravis, there is probably no central effect of the anti-muscle AChR antibodies.

Now that the structures of these nicotinic AChRs from brains of chickens, rats, cattle, and, to some extent, humans have been defined, and the cDNAs for some of these proteins identified, the next major step may be to determine the function of these neuronal AChRs both at the molecular level and at the level of synaptic transmission and brain function. Many different approaches will be required to resolve these issues.

\section{References}

Boulter, J., K. Evans, D. Goldman, G. Martin, D. Treco, S. Heinemann, and J. Patrick (1986) Isolation of a cDNA clone coding for a possible neuronal nicotinic acetylcholine receptor alpha subunit. Nature 319: 368-374.

Boyd, R. I., M. H. Jacob, M. Ballivet, J. Patrick, and D. L. Berg (1987) Expression of neuronal acetylcholine receptor MRNA in chick ciliary ganglia. Soc. Neurosci. Abstr. 13: 223.4.

Chiappinelli, V.A. (1985) Actions of snake venom toxins on neuronal nicotinic receptors and other neuronal receptors. Pharmacol. Ther. 31: 1-32.

Conti-Tronconi, B. M., S. M. J. Dunn, E. A. Barnard, J. O. Dolly, F. A. Lai, N. Ray, and M. A. Raftery (1985) Brain and muscle nicotinic acetylcholine receptors are different but homologous proteins. Proc. Natl. Acad. Sci. USA 82: 5208-5212.

Deneris, E. S., J. Connolly, J. Boulter, E. Wada, K. Wada, L. W. Swanson, J. Palrick, and S. Heinemann (1988) Primary structure and expression of $\beta \alpha$ : A novel subunit of neuronal nicotinic acetylcholine receptors. Neuron $1:$ 45-54.

Flynn, D. D., and D. C. Mash (1986) Characterization of $\mathrm{L}^{-3} \mathrm{H}$ nicotine binding in human cerebral cortex: Comparison between Alzheimer's disease and the normal. J. Neurochem. 47: 1948-1954.

Gershoni, J. M., E. Hawrot, and T. L. Lentz (1983) Binding of $\alpha$ bungarotoxin to isolated $\alpha$-subunit of the acetylcholine receptor of Torpedo californica: Quantitative analysis with protein blots. Proc. Natl. Acad. Sci. USA 80: 4973-4977.

Goldman, D., D. Simmons, L. W. Swanson, J. Patrick, and S. Heinemann (1986) Mapping of brain areas expressing RNA homologous to two different acetylcholine receptor $\alpha$-subunit cDNAs. Proc. Natl. Acad. Sci. USA 83: 4076-4080.

Goldman, D., E. Deneris, W. Luyten, A. Kochhar, J. Patrick, and S. Heinemann (1987) Members of a nicotinic acetylcholine receptor gene family are expressed in different regions of the mammalian central nervous system. Cell 48: 965-973.

Grenningloh, G., A. Rienitz, B. Schmitt, C. Methfessel, M. Zensen, K. Beyreuther, E. Gundelfinger, and H. Betz (1987) The strychnine binding subunit of the glycine receptor shows homology with nicotinic acetylcholine receptors. Nature 328: 215-220.

Halvorsen, S. W., and D. K. Berg (1986) Identification of a nicotinic acetylcholine receptor on neurons using an alpha-neurotoxin that blocks receptor function. J. Neurosci. 6: 3405-3412.

Halvorsen, S. W., and D. K. Berg (1987) Affinity labelling of neuronal acetylcholine receptor subunits with an $\alpha$-neurotoxin that blocks receptor function. J. Neurosci. 7: 2547-2555.

Higgins, L. S., and D. K. Berg (1987) Immunological identification of a nicotinic acetylcholine receptor on bovine chromaffin cells. J. Neurosci. 7: 1792-1798.

Hochschwender, S., L. Langeberg, D. Schneider, and J. Lindstrom (1985) Production of rat $\times$ mouse hybridomas for the study of the nicotinic acetylcholine receptor. In Hybridoma Technology in the Biosciences and Medicine, T. A. Springer, ed., pp. 223-238, Plenum, New York

Jacob, M. H., D. K. Berg, and J. M. Lindstrom (1984) Shared antigenic determinant between the Electrophorus acetylcholine receptor and a synaptic component on chicken ciliary ganglion neurons. Proc. Natl. Acad. Sci. USA 81: 3223-3227.

Kao, P. N., A. J. Dwork, R. J. Kaldany, M. L. Silver, J. Wideman, S. Stein, and A. Karlin (1984) Identification of the alpha subunit half cystine specifically labelled by an affinity rcagent for the acctylcholinc receptor binding site. J. Biol. Chem. 259: 11662-11665.

Kemp, G., and B. J. Morley (1986) Ganglionic AChRs and high affinity nicotinic binding sites are not equivalent. FEBS Lett. 205: 265-268.

Leprince, P. (1983) Chemical modification of the nicotinic cholinergic receptor of PC-12 nerve cell. Biochemistry 22: 5551-5556.

Lindstrom, J. (1985) Immunobiology of myasthenia gravis, experimental autoimmune myasthenia gravis and Lambert-Eaton syndrome. Annu. Rev. Immunol. 3: 109-131.

Lindstrom, J., W. J. Gullick, B. Conti-Tronconi, and M. Ellisman (1980) Proteolytic nicking of the acetylcholine receptor. Biochemistry 19: $4791-4795$. 
Lindstrom, J., B. Einarson, and S. Tzartos (1981) Production and assay of antibodies to acetylcholine receptors. Methods Enzymol. 74: $432-460$.

Lindstrom, J., S. Tzartos, W. Gullick, S. Hochschwender, L. W. Swanson, P. Sargent, M. Jacob, and M. Montal (1983) Use of monoclonal antibodies to study acetylcholine receptors from electric organs, muscle, and brain and the autoimmune response to receptor in myasthenia gravis. Cold Spring Harbor Symp. Quant. Biol. 48: 89-99.

Lindstrom, J., R. Schoepfer, and P. Whiting (1987) Molecular studies of the neuronal nicotinic acetylcholine receptor family. Mol. Neurobiol. 1: 281-337.

Martin, B. R. (1986) Nicotine receptors in the central nervous system. In The Receptors, vol. 3, P. M. Conn, ed., pp. 313-415, Academic, New York.

Merlie, J. P., R. Scbbanc, S. Tzartos, and J. Lindstrom (1982) Inhibition of glycosylation with tunicamycin blocks assembly of newly synthesized acetylcholine receptors subunits in muscle cells. J. Biol. Chem. 257: 2694-2701.

Nef, P., C. Oneyser, T. Barkas, C. Alliod, S. Couturier, and M. Ballivet (1988) Genes expressed in the brain define three distinct neuronal nicotinic acetylcholine receptors. EMBO J. 7: 595-601.

Oakley, B., D. R. Kirsch, and N. R. Morris (1980) A simplified ultrasensitive silver stain for detecting proteins in polyacrylamide gels. Anal. Biochem. 105: 361-363.

Perry, E. K., R. H. Perry, C. J. Smith, D. J. Dick, J. M. Candy, J. A. Edwardson, A. Fairbairn, and G. Blessed (1987) Nicotinic receptor abnormalities in Alzheimer's and Parkinson's diseases. J. Neurol. Neurosurg. Psychiatry 50: 806-809.

Popot, J. L., and J. P. Changeux (1984) Nicotinic receptor of acetylcholine: Structure of an oligomeric membrane protein. Physiol. Rev. 64: 1162-1239.

Schoepfer, R, P. Whiting, F. Esch, R. Blacher, S. Shimasaki, and J. Lindstrom (1988) cDNA clones coding for the structural subunit of a chicken brain nicotinic acetylcholine receptor. Neuron 1: 241-248.

Schofield, P., M. G. Darlison, N. Fujita, D. R. Burt, F. A. Stephenson, H. Rodriquez, L. M. Rhee, J. Ramachardran, V. Reale, T. A. Glencorse, P. Seeberg, and E. A. Barnard (1987) Sequence and functional expression of the $\mathrm{GABA}_{\mathrm{A}}$ receptor shows a ligand-gated receptor superfamily. Nature 328: 221-227.

Schwartz, R. D., R. McGee, and K. J. Kellar (1982) Nicotinic cholinergic receptors labelled by $\left[{ }^{3} \mathrm{H}\right]$ acetylcholine in rat brain. Mol. Pharmacol. 22: 56-62.

Shimohama, S., T. Taniguchi, M. Fujiwara, and M. Komeyama (1986) Changes in nicotinic and muscarinic cholinergic receptors in Alzheimer type dementia. J. Neurochem. 46: 288-293.

Smith, M. A., J. Stollberg, D. K. Berg, and J. M. Lindstrom (1985) Characterization of a component in chick ciliary ganglia that crossreacts with monoclonal antibodies to muscle and electric organ acetylcholine receptor. J. Neurosci. 5: 2726-2731.

Smith, M. A., J. F. Margiotta, A. Franco, Jr., J. M. Lindstrom, and D. $\mathrm{K}$. Berg (1986) Cholinergic chick ciliary ganglion neurons in culture. J. Neurosci. 6: 946-953.

Stollberg, J., P. J. Whiting, J. M. Lindstrom, and D. K. Berg (1986) Functional blockade of neuronal acetylcholine receptors by antisera to a putative receptor from brain. Brain Res. $378: 179-182$.

Swanson, L. W., J. Lindstrom, S. Tzartos, L. Schmued, D. D. O'Leary, and W. M. Cowan (1983) Immunohistochemical localization of monoclonal antibodies to the nicotinic acetylcholine receptor in the midbrain of the chick. Proc. Natl. Acad. Sci. USA 80: 4532-4536.

Swanson, L. W., D. M. Simmons, P. J. Whiting, and J. M. Lindstrom (1987) Immunohistochemical localization of neuronal nicotinic receptors in the rodent central nervous system. J. Neurosci. 7: 33343342.

Tzartos, S., and J. M. Lindstrom (1980) Monoclonal antibodies used to probe acetylcholine receptor structure: Localization of the main immunogenic region and detection of similarities between subunits. Proc. Natl. Acad. Sci. USA 77: 755-759.

Tzartos, S. J., D. E. Rand, B. E. Einarson, and J. M. Lindstrom (1981) Mapping of surface structure of Electrophorus acctylcholine rcceptor using monoclonal antibodies. J. Biol. Chem. 256: 8635-8645.

Wada, K., M. Ballivet, J. Boulter, J. Connolly, E. Wada, E. Deneris, L. Swanson, S. Heinemann, and J. Patrick (1988) Functional expression of a new pharmacological subtype of brain nicotinic acetylcholine receptor. Science 240:330-334.

Watson, J., E. Adkins-Regan, P. Whiting, J. Lindstrom, and T. Podleski (1988) Autoradiographic determination of the distribution of nicotinic acetylcholine receptors in the zebra finch brain. J. Compar. Neurol. (in press).

Whiting, P. J., and J. M. Lindstrom (1986a) Purification and characterization of a nicotinic acetylcholine receptor from chick brain. Biochemistry 25: 2082-2093.

Whiting, P. J., and J. M. Lindstrom (1986b) Pharmacological propcrtics of immunoisolated ncuronal nicotinic receptors. J. Neurosci. 6: 3061-3069.

Whiting, P. J., and J. M. Lindstrom (1987a) Purification and characterization of a nicotinic acetylcholine receptor from rat brain. Proc. Natl. Acad. Sci. USA 84: 595-599.

Whiting, P. J., and J. M. Lindstrom (1987b) Affinity labeling of neuronal acetylcholine receptors localizes acetylcholine binding sites to their $\beta$ subunits. FEBS Lett. 213: 55-60.

Whiting, P. J., J. Cooper, and J. M. Lindstrom (1987a) Antibodies in sera from patients with myasthenia gravis do not bind to nicotinic acetylcholine receptors from human brain. J. Neuroimmunol. 16 . 205-213.

Whiting, P. J., F. Esch, S. Shimasaki, and J. Lindstrom (1987b) Neuronal nicotinic acetylcholine receptor $\beta$ subunit is coded for by the cDNA clonc $\alpha_{4}$. FEBS Lett. 219: 459-463.

Whiting, P. J., R. Liu, B. J. Morley, and J. M. Lindstrom (1987c) Structurally different neuronal nicotinic acetylcholine receptor subtypes purified and characterized using monoclonal antibodies. J. Neurosci. 1: 4005-4016.

Whiting, P. J., R. Schoepfer, L. W. Swanson, D. M. Simmons, and J. Lindstrom (1987d) Functional acetylcholine receptor in PC12 cells reacts with a monoclonal antibody to brain nicotinic receptors. Nature 327: 515-518.

Wonnacott, S. (1987) Brain nicotine binding sites. Human Toxicol. 6: 343-353. 